\title{
An Experimental and Numerical Analysis of Puff Hydrodynamics*
}

\author{
by \\ Mohammad S. Saidi ${ }^{1,2}$, Mohammad R. Hajaligol $^{2}$, and Firooz Rasouli ${ }^{2}$ \\ ${ }^{1}$ Isfahan University of Technology, Isfahan, Iran \\ ${ }^{2}$ Research Center, Philip Morris USA, Richmond, Virginia 23234, USA
}

\section{SUMMARY}

The permeability of a tobacco rod in a cigarette increases as it converts into char and ash in the coal. The hot coal introduces a significant resistance to the air flow when air passes through. Through a series of experiments, the cigarette burn line and burn rate, the centerline temperature, and the pressure drop were measured for continuous puffing conditions. The gas viscosity was calculated from the temperature distribution inside the cigarette and applying Sutherland's law. Then, the experimental setup was mathematically modeled from a commercially available CFD (Computational Fluid Dynamics) code and, by matching the numerical and experimental results, the changes in coal and filter permeability during puffing were estimated. The numerical simulation successfully reproduced the results of experiments on the air flow through the coal, ventilation holes and paper wrapper. [Beitr. Tabakforsch. Int. 21 (2004) 157-166]

\section{ZUSAMMENFASSUNG}

Die Permeabilität des Tabakstrangs einer Zigarette steigt an, wenn sich der Tabak in der Glutzone zu Kohle und Asche umwandelt. Die heiße Glut verursacht einen signifikanten Luftwiderstand, wenn Luft durch den Tabakstrang strömt. In einer Reihe von Experimenten wurde die Brennlinie und die Abbrandgeschwindigkeit der Zigaretten sowie die Temperatur an der Mittellinie und der Druckabfall während der Züge gemessen. Die Viskosität des Gases wurde auf der Basis der Temperaturverteilung in der Zigarette und unter Anwendung von Sutherlands Gesetz berechnet. Die Versuchsanordnung wurde dann mit einem kommerziellen Programm zur Berechnung der Flussdynamik (CFD, Computational Fluid Dynamics) modelliert. Durch Angleichung der numerischen und der experimentellen Werte wurde die Änderung der Permeabilität der
Glutzone und des Filters während eines Zuges geschätzt. Durch die rechnerische Simulation ließen sich die Ergebnisse der experimentellen Untersuchungen über den Luftstrom durch die Glutzone, die Ventilationslöcher und das Umhüllungspapier erfolgreich reproduzieren. [Beitr. Tabakforsch. Int. 21 (2004) 157-166]

\section{RESUME}

La perméabilité du boudin de tabac d'une cigarette augmente quand il est converti en charbon et cendre dans le cône de combustion. Le cône incandescent introduit une résistance significative aux flux d'air passant à travers le boudin de tabac. Dans une série d'essais, la ligne et la vitesse de combustion d'une cigarette ainsi que la température au niveau de la zone médiane et la perte de charge ont été mesurées au cours des bouffées. La viscosité du gaz a été calculée à partir de la distribution de la température au sein de la cigarette et en appliquant la loi de Sutherland. Les essais ont été mathématiquement modélisés par une technique CFD (Computational Fluid Dynamics) disponible dans le commerce. Les changements de la perméabilité du cône de combustion et du filtre au cours de la bouffée ont été estimés par une méthode de comparaison des résultats numériques et expérimentaux. La simulation numérique a reproduit de façon satisfaisante les résultats des essais sur le flux d'air à travers le cône, les trous de ventilation et l'enveloppe de papier. [Beitr. Tabakforsch. Int. 21 (2004) 157-166]

\section{INTRODUCTION}

Modeling of the smoldering process in general and especially in a cigarette is very complex for various reasons, among them, the lack of a clear understanding of physical phenomena, the unavailability of crucial input data for the 
model, and the computational complexity associated with modeling highly nonlinear coupled processes. The problem becomes even more complicated when one tries to model a system with a sequence of natural and forced smoldering cycles while it is interacting with its surroundings. In spite of several decades of effort, we are not even close to having a comprehensive model to reasonably predict the chemical and physical changes of a system undergoing the smoldering process.

The numerical simulation of cigarette burning involves different processes and mechanisms reviewed in detail by OHLEMILLER (1). By solving the Navier-Stokes equations along with the continuity equation, and taking into account the permeability of different parts of the cigarette and the effect of porosity, the hydrodynamics of a burning cigarette is simulated. The outputs are the velocity and pressure distributions inside a cigarette and its vicinity. The next steps are to add the pyrolysis model and to calculate the char density as the burn line sweeps the cigarette, followed by adding the combustion model. Considering both local mass transfer rates and the reaction rates of combustion products and volatile gases produced, the energy equation is solved to obtain the temperature distribution. The transport equations along with the mass diffusion coefficients for the multi-species through the porous media predict the propagation of gaseous species. Modeling the aerosol nucleation, coagulation, deposition, condensation and evaporation simulates the transport and change of smoke in the cigarette bed. Modeling the transport processes involved in the above mentioned steps, among many other parameters, requires the velocity field throughout the cigarette. So far, the mathematical modeling of the cigarette has been limited to one and two-dimensional models. Although the cigarette is geometrically symmetric, due to the presence of natural convection, the cigarette burning is actually asymmetric.

Among the one-dimensional mathematical models, one may refer to the works of SUMMERFIELD et al. (2) on modeling steady-draw smoking, NORBURY and STUART (3) on presenting a transport model for porous medium combustion, KANSA (4) for modeling charring pyrolysis, including porous and permeable structures, LEACH et al. (5) for presenting a transient model for forward smoldering, MURAMATSU et al. (6) for modeling natural smoldering of a cigarette, and SANDUSKY et al. (7) for modeling the forced smoldering (puffing) of a cigarette. Among twodimensional models, one may refer to the work done by DI BLASI (8) for modeling the combustion processes of charring and non-charring solid fuels of slab geometry and YI et al. (9) for developing a steady state model for smoldering of a cylindrical geometry. Finally, RosTAMI et al. presented a transient model based on first principles for both natural (10) and forward smoldering $(11,12)$ of a cigarette which considers the smoldering domain to have two independent phases of solid and surrounding gas interacting at the interfaces.

The works presented on puff hydrodynamics and flow distribution are mainly oriented on ventilation studies. One may refer to BAKER's paper (13) for a review of some of the work done in this area. BAKER (14), DELUCIA et al. (15), MASUO et al. (16), OWEN (17) and TERAHARA et al. (18) have studied the effect of physical dimensions and parameters of the cigarette, the type of cigarette paper, and details of the filter ventilation zone (such as position of the zone, size and number of holes) on the magnitude of ventilation. NORMAN (19) has measured the puff-by-puff ventilation of different cigarettes, MASUO et al. (20) have studied the effect of rod paper perforation and filter ventilation on air influx, BAKER (21) has calculated the velocity distribution inside the coal from the pressure and temperature measurements inside the cigarette correlated with the flow velocity through Darcy's law, and finally, SCHNEIDER (22) has developed a computational model which predicts the effects of various combinations of cigarette parameters on ventilation. The above-mentioned works are either experimental or empirical and lack a direct numerical simulation of puff hydrodynamics.

In this work, we model and analyze the hydrodynamics of cigarette coal during puffing by use of a three dimensional domain that can be readily applied to problems with body force in the future. Unlike the previous works, the surrounding air is included in the computational domain, and thus the cigarette-surrounding environment boundary is naturally treated without imposing boundary conditions at the cigarette surface. Rather, the boundary condition is imposed on the far field boundary, where the effect of the cigarette is negligible and pressure and temperature can be set to the relevant background values as the boundary conditions.

Once the coal at the tip of a lit cigarette is developed, the flow distribution through and around the coal will become very different from that of an unlit cigarette. This is due to the development of a new porous structure that has a different permeability than the original material, and the increasing gas viscosity in the combustion zone (coal). As the tobacco decomposes due to pyrolysis and converts into char, its density decreases, and as the char is burned in the coal, its density is further decreased. This process of decreasing density results in a continuous increase in the bed permeability. On the other hand, the deposition of the smoke aerosols in the filter may change the filter permeability. We concluded that the behavior of pressure drop can be explained by assuming that total particulate matter (TPM) delivery to the filter actually decreases its permeability, and obtained a correlation between the amount of TPM delivery and filter permeability.

This model is based on the fact that a change in flow distribution induces a change in pressure drop. Therefore, one may correlate pressure drop to local permeability. But since in this process, the bed permeability is not the sole parameter that is changing, a direct, explicit correlation cannot be derived. Thus an implicit method is applied. That is to say, the condition of the experimental set up is modeled numerically, and by trial and error, the correct value of the bed permeability that matches the calculated pressure drop with the experimental one is determined.

\section{EXPERIMENTAL SETUP}

A schematic of the experimental setup is shown in Figure 1. The cigarette was placed in a vertical position to avoid the non-uniform effects of natural convection if it is placed horizontally and to enhance a horizontal burn line. The 


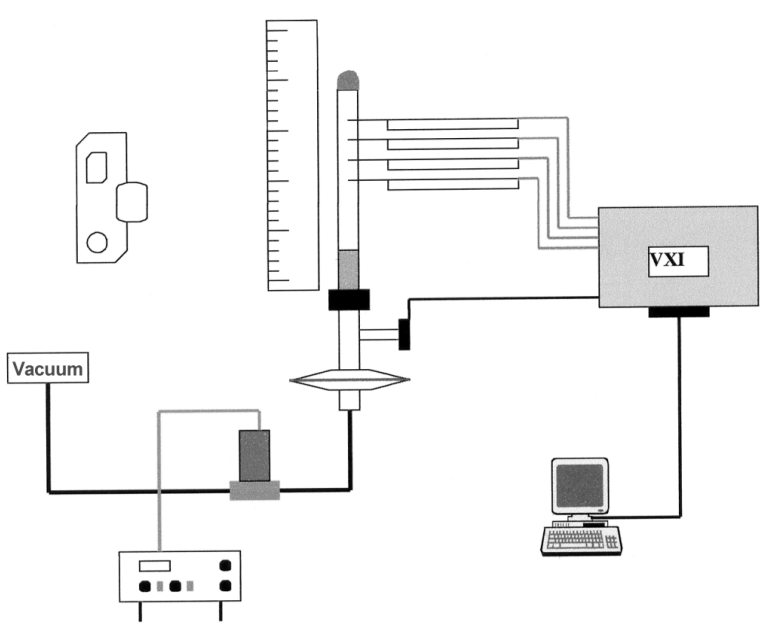

Figure 1. Permeability measurement setup

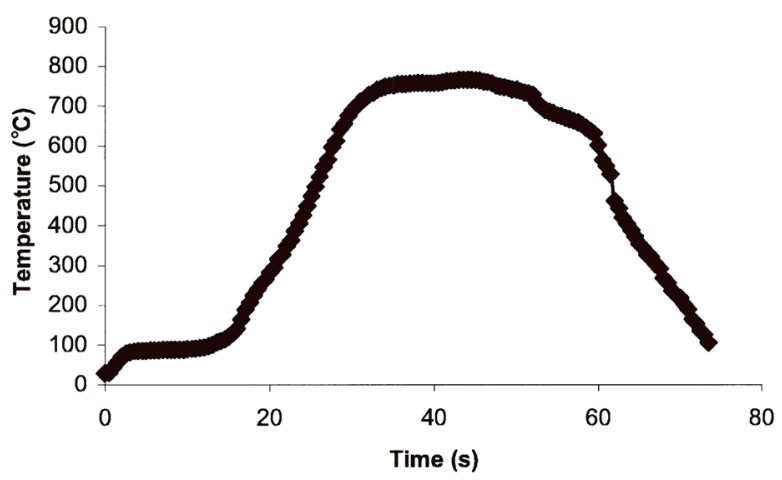

Figure 2. The average centerline temperature variation with time $\left(6.67 \mathrm{~cm}^{3} / \mathrm{s}\right)$

spatial and temporal variation of cigarette temperature (gas phase) along the centerline was measured by placing thermocouples $5 \mathrm{~mm}$ apart starting from the tip. A pressure transducer measured the time variation of pressure at the cigarette outlet, and the changes in the tip and burn line with time were monitored by taking pictures at specified times. To have a uniform and steady burn during continuous puffing, the air flow rate was reduced to $6.67 \mathrm{~cm}^{3} / \mathrm{s}$ and below.

\section{EXPERIMENTAL RESULTS}

The thermocouples located at different locations of the cigarette produced similar time-variant profiles for temperature. The measurement was repeated several times to obtain an average temperature profile which is given in Figure 2. Different zones of the cigarette bed during continuous puffing can also be distinguished in Figure 2. The first zone is flat, which is due to evaporation of the moisture from the tobacco shreds. In the second zone, there is an abrupt increase of temperature in the pyrolysis zone in which most of tobacco decomposition is reached. The third zone is a high temperature combustion zone with less variation of temperature with time; and, finally the sharp decrease of temperature is the cooling zone (ash).

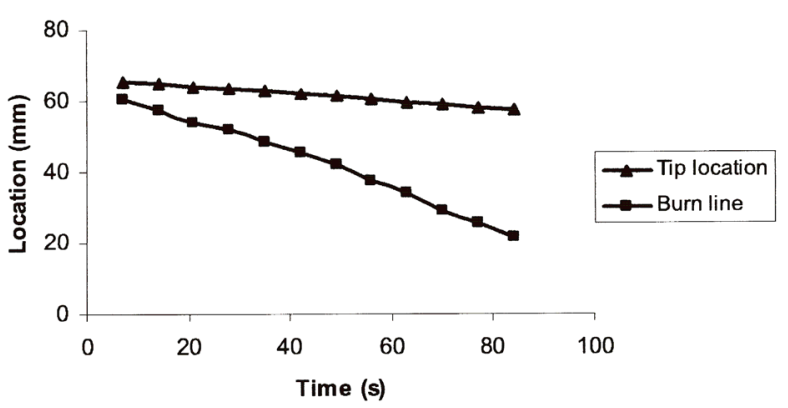

Figure 3. The tip and burn line location of a burning cigarette $\left(6.67 \mathrm{~cm}^{3} / \mathrm{s}\right)$

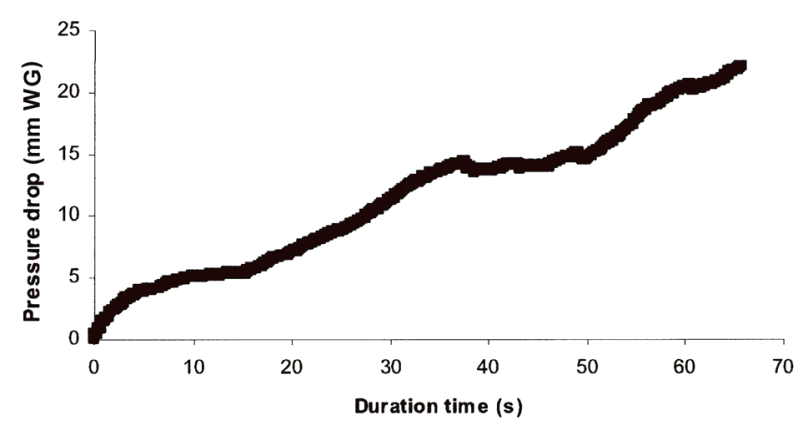

Figure 4. The average increase of pressure drop after lighting the cigarette

Figure 3 shows the locations of the tip and the burn line as a function of time. The slopes of the curves represent the rate of cigarette shortening $(0.092 \mathrm{~mm} / \mathrm{s})$ and the speed of the burn line $(0.44 \mathrm{~mm} / \mathrm{s})$. We should note that during the experiment, the ash was not removed, and the total length of the cigarette, including the ash, shortened during puffing. If we consider the coal to be in the region beginning at a temperature of $450{ }^{\circ} \mathrm{C}$, going over the plateau with $750{ }^{\circ} \mathrm{C}$, and ending at $650{ }^{\circ} \mathrm{C}$, Figure 2 shows that it takes 38 seconds for the coal to pass a thermocouple. The outlet pressure of a cigarette was first measured with a continuous flow of air before it was lit. Under a similar continuous flow of air, when the cigarette is lit, the pressure measurement shows a drop in the outlet pressure. Since the flow rate is kept constant during the experiment and smoking is under suction, the increase in pressure drop due to coal formation causes the pressure at the outlet to decrease. The change in pressure outlet relative to the case of continuous puffing before lighting the cigarette was calculated. Figure 4 shows the average calculated values of outlet pressure change from different experiments. The coal length for continuous puffing may be estimated from the speed of the burn line and the time interval that the coal traverses a thermocouple, which would be about $16.7 \mathrm{~mm}$ for a flow rate of $6.67 \mathrm{~cm}^{3} / \mathrm{s}$.

\section{MATHEMATICAL MODELING}

Given the temperature distribution inside the cigarette from the experiments, the continuity and Navier-Stokes equations are sufficient to determine the velocity and pressure 


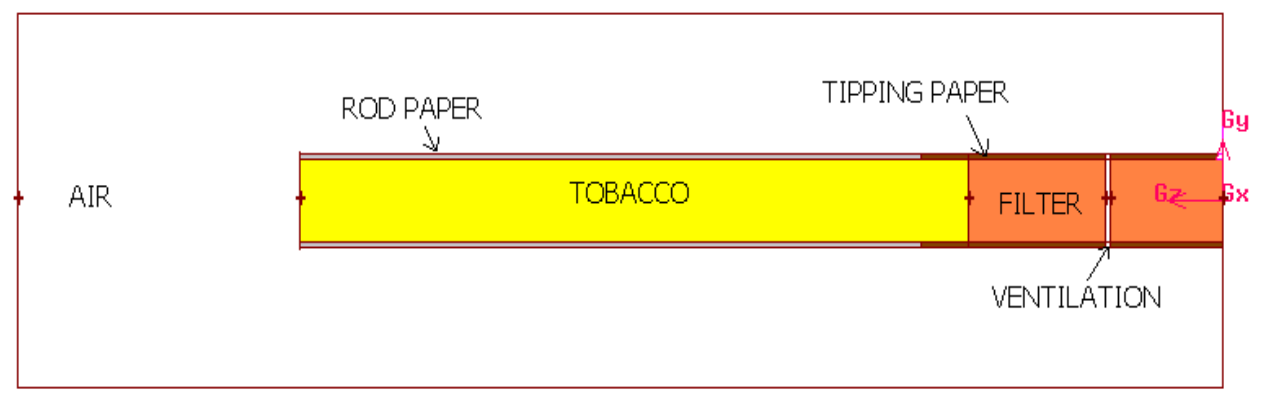

Figure 5. Schematic view of a cigarette

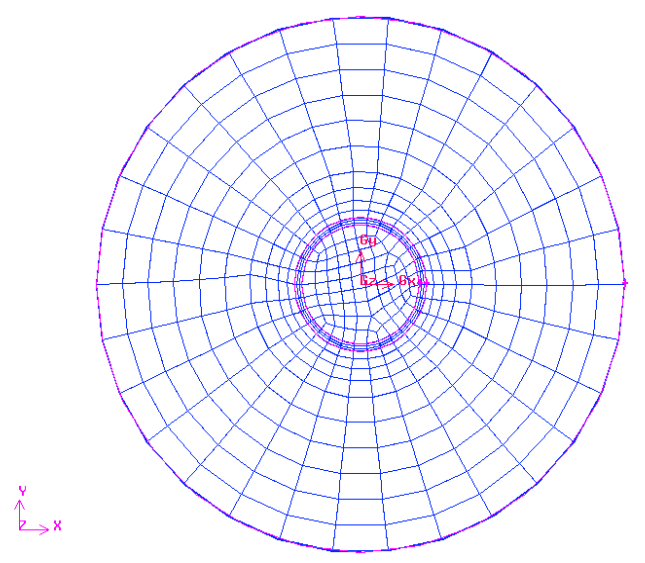

Figure 6. Grid frontal view

distributions. The general form of momentum equations for incompressible flow in a porous media such as a cigarette is given as:

$$
\frac{\partial \rho \boldsymbol{V}}{\partial t}+(\boldsymbol{V} \times \Delta)(\rho \boldsymbol{V})=\Delta \times(\mu \Delta) \boldsymbol{V}+\mathrm{SOURCE}
$$

The effect of porosity on flow distribution is accounted for by adding a source term to the momentum equation. The source term is derived from Darcy's law (23):

$$
\text { SOURCE }=\frac{\mu}{K} \boldsymbol{V}+C \rho|\boldsymbol{V}| \boldsymbol{V}
$$

where $K$ is the bed permeability, $\rho$ and $\mu$ are gas density and viscosity, and $C$ is a constant. Given the fact that even during puffing the velocity is small (less than $0.4 \mathrm{~m} / \mathrm{s}$ ), the contribution of the second order term of Eqn. [2] is negligible.

The effect of temperature on gas viscosity $(\mu)$ is implemented with Sutherland's law (24):

$$
\mu=\frac{C_{1} T^{3 / 2}}{T+C_{2}}
$$

where $C_{1}=1.458 \times 10^{-6} \mathrm{~kg} / \mathrm{m} \cdot \mathrm{s} \cdot K^{1 / 2}$ and $C_{2}=110.4 K$. We used the 3-D computational fluid dynamics code, Fluent 6.0.2, to solve the above series of equations. Fluent uses a control-volume-based technique. Therefore, momentum equations are discretized using a control volume method. The
Table 1. Physical properties of the cigarette

\begin{tabular}{l|c}
\hline Parameters & Values \\
\hline Tobacco region permeability & $5.7 \times 10^{-10} \mathrm{~m}^{2}$ \\
Filter permeability & $2.5 \times 10^{-10} \mathrm{~m}^{2}$ \\
Rod paper permeability & $4.87 \times 10^{-15} \mathrm{~m}^{2}$ \\
Ash permeability & $1.0 \times 10^{-20} \mathrm{~m}^{2}$ \\
Burnt paper permeability & $1.0 \times 10^{-20} \mathrm{~m}^{2}$ \\
Ventilation equivalent permeability & $1.14 \times 10^{-13} \mathrm{~m}^{2}$ \\
Cigarette radius & $4.0 \mathrm{~mm}$ \\
Cigarette length & $98.0 \mathrm{~mm}$ \\
\hline
\end{tabular}

pressure and velocity coupling was done through the continuity equation by use of the SIMPLEC (25) algorithm. The second order scheme, QUICK (26), was chosen for momentum flux calculation through an implicit segregated solver. Fluent is customized to the problem with extensive application of the advanced feature of the code, user defined functions (UDF) (27). The different values of permeability of the tobacco region, paper, burned paper, and coal were introduced in Eqn. [2] from the UDF of the code.

\section{NUMERICAL ANALYSIS}

Figure 5 shows a schematic of a cigarette and the surrounding air. The cigarette with a diameter of $8 \mathrm{~mm}$ is composed of a $72 \mathrm{~mm}$ length tobacco region and $27 \mathrm{~mm}$ length filter wrapped with rod paper and impermeable tipping paper. The tipping paper is perforated at the mid-section. The computational domain comprises the cigarette and its surrounding air. Since the flow gradients across the cigarette are uniform, an unstructured body fitted grid with approximately equal cell sizes was used. For the outer region, a structured grid with an increasing cell size with radius was applied. Figure 6 shows the cross sectional view of the generated grid. The portion referring to the rod paper is exaggerated to be seen in the above figures.

In order to achieve grid independent numerical results, a grid study was performed comparing three grids with different mesh sizes, as specified in Table 1. The pressure boundary conditions on the far field were set at zero static gauge pressure, and at the cigarette outlet, at $-1148 \mathrm{~Pa}$. The mass flow rates across the outlet, tip, rod paper, and perforation surfaces were calculated for the three grids. The results are shown in Table 2 which shows a maximum 
Table 2. Mass flow rates calculated for different mesh sizes

\begin{tabular}{l|c|c|c|c|c|c}
\hline Case & $\begin{array}{c}\text { Cell size } \\
(\mathrm{mm})\end{array}$ & $\begin{array}{c}\text { Number of } \\
\text { cells }\end{array}$ & $\begin{array}{c}\text { Outlet mass flow rate } \\
10^{-6} \mathrm{~kg} / \mathrm{s}\end{array}$ & $\begin{array}{c}\text { Tip surface mass flow rate } \\
10^{-6} \mathrm{~kg} / \mathrm{s}\end{array}$ & $\begin{array}{c}\text { Rod paper mass flow rate } \\
10^{-6} \mathrm{~kg} / \mathrm{s}\end{array}$ & $\begin{array}{c}\text { Ventilation mass flow rate } \\
10^{-6} \mathrm{~kg} / \mathrm{s}\end{array}$ \\
\hline A & 1.5 & 19491 & 18.61 & 11.63 & 4.63 & 2.76 \\
B & 1.0 & 57112 & 19.62 & 12.01 & 4.87 & 2.81 \\
C & 0.67 & 170914 & 19.97 & 12.45 & 5.02 & 2.83 \\
\hline
\end{tabular}

Table 3. Geometrical specifications of computational domain

\begin{tabular}{l|c|c|c|c}
\hline Case & Radial extent & Axial extent & $\begin{array}{c}\text { Cell size } \\
(\mathrm{mm})\end{array}$ & $\begin{array}{c}\text { Number } \\
\text { of cells }\end{array}$ \\
\hline C & $\begin{array}{c}4 \times \text { cigarette } \\
\text { radius }\end{array}$ & $\begin{array}{c}7.5 \times \text { cigarette } \\
\text { radius }\end{array}$ & 1.0 & 57112 \\
D & $\begin{array}{c}8 \times \text { cigarette } \\
\text { radius }\end{array}$ & $\begin{array}{c}15 \times \text { cigarette } \\
\text { radius }\end{array}$ & 1.0 & 117208 \\
\hline
\end{tabular}

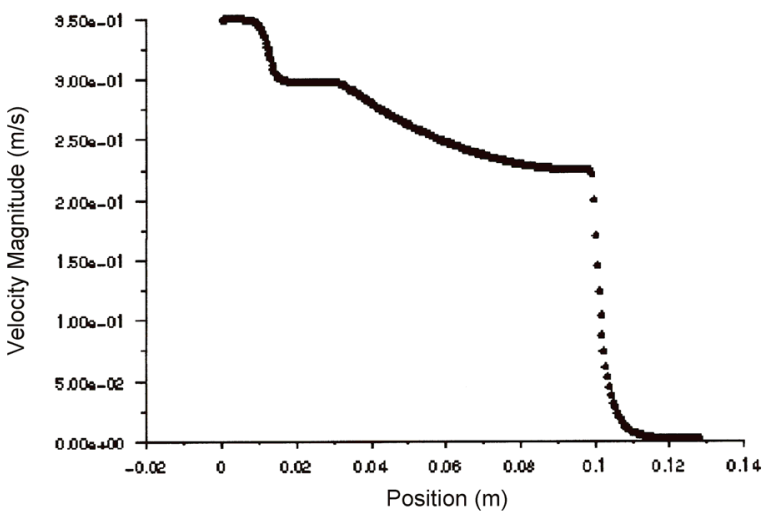

Figure 7. Velocity magnitude distribution along the centerline

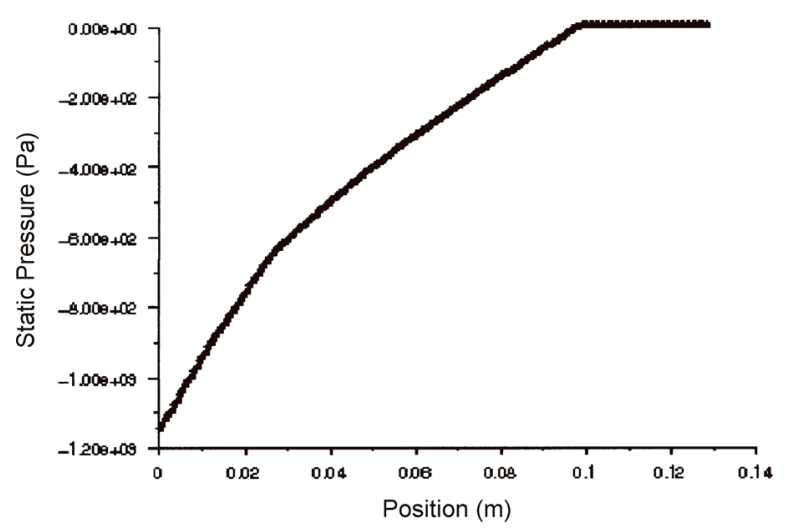

Figure 8. Pressure distribution along the centerline

difference of $0.5 \%$ in all mass flow rates. Another study was conducted to assure that the extent of the far field boundary is large enough. The results of two cases that indicate the difference in mass flow rates across all the above surfaces was less than $0.4 \%$ for the two grids are given in Table 3. Grid B, which has a moderate number of cells, was chosen in the rest of studies.

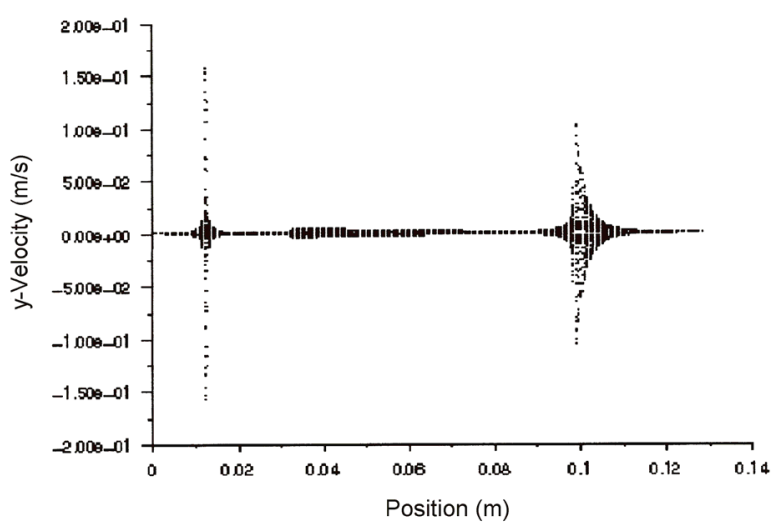

Figure 9. The y-component of velocity on planar surface

Three different situations were numerically simulated, namely continuous puffing of an unlit cigarette, continuous puffing of a lit cigarette, and the puff-by-puff smoking of a lit cigarette.

\section{Continuous puffing in an unlit cigarette}

The hydrodynamics of an unlit cigarette under a continuous flow of $6.67 \mathrm{~cm}^{3}$ (400 cc/min) was first studied. Figures 7 and 8 show the velocity magnitude and pressure along the cigarette centerline, respectively. The air velocity as shown in Figure 7 is zero outside the cigarette and starts to increase rapidly as we approach the cigarette tip (located at $0.01 \mathrm{~m}$ ). Inside the cigarette, the velocity gradually increases due to the inflow of air through the wrapper paper. In the tipping paper zone, where the paper is impermeable, there is no influx of air and the velocity remains constant. In the mid-section of this zone, where there is ventilation, the velocity increases sharply and again remains constant. The pressure (gauge), as shown in Figure 8, is zero outside of the cigarette and it begins to decrease within the cigarette from the tip. The slope of the curve remains constant throughout the rod, but it slightly increases in the filter (located at $0.03 \mathrm{~m}$ ) due to a velocity increase in this region. This is expected as the filter has a lower permeability compared to the tobacco rod. The rate of pressure drop in the filter remains constant with a slight change when the ventilation air is introduced.

Figure 9 shows the radial component of the velocity distribution on the wrapper paper. As expected, larger values for the velocity around the cigarette tip and ventilation zone, and a measurable value on the permeable part of the wrapper paper can be observed. These results clearly indicate that the velocity magnitude, and pressure are radially uniform throughout the cigarette and filter except at and around the tip and ventilation zone. 


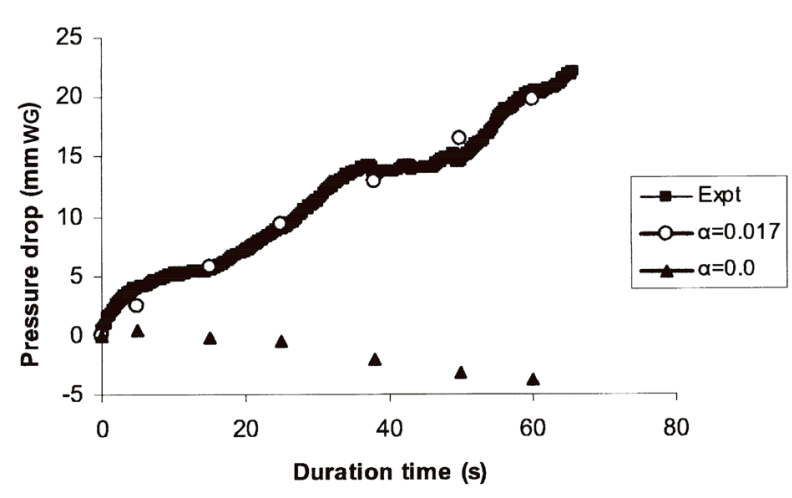

Figure 10. The relative increase of outlet pressure $\left(6.67 \mathrm{~cm}^{3} / \mathrm{s}\right)$

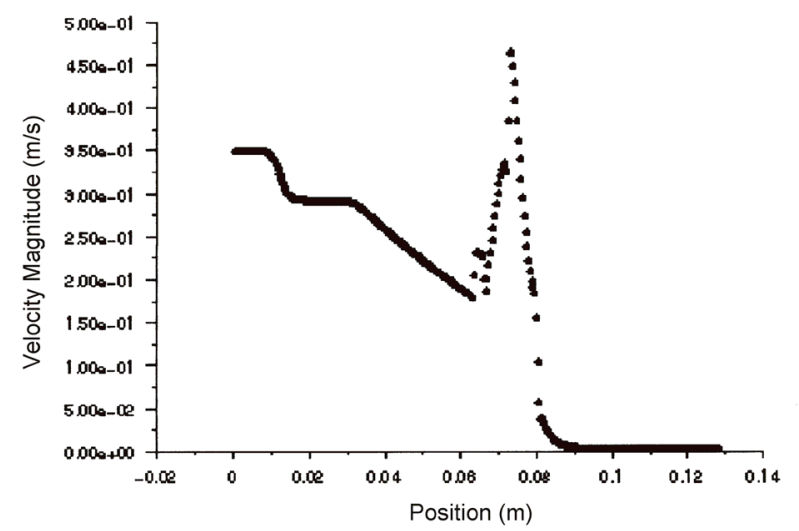

Figure 11. The velocity magnitude along the cigarette centerline

\section{Continuous puffing in a lit cigarette}

To simulate numerically the continuous puffing experiments, a radially uniform temperature distribution was assumed throughout the cigarette from the measured temperatures. The locations of the cigarette tip and the burn line change with time as estimated from the experimentally measured values for burn line, tip, and coal length. From a density profile for the column of the burning cigarette as given by MURAMATSU (6), the permeability of the tobacco column can be estimated such that at one end we have permeability of unchanged tobacco and at the other end we have ash permeability.

First the outlet pressure for the unlit cigarette $\left(P_{0}\right)$ at 6.67 $\mathrm{cm}^{3} / \mathrm{s}$ flow rate was calculated. Then the numerical simulation was performed for a burning cigarette for different time duration to calculate the outlet pressure $\left(P_{t}\right)$. We then defined a relative outlet pressure as $P_{\mathrm{t}}-P_{0}$, and plotted it as a function of time as given in Figure 10. From the calculations, it is noticed that $P_{\mathrm{t}}$ is decreasing with time. When the cigarette is lit under continuous puffing, the centerline temperature at any given location, the coal and filter permeabilities, and the rod length change with time contributing different effects on $P_{\mathrm{t}}$. The temperature increase in the coal increases $P_{\mathrm{t}}$ while a higher permeability in the coal and shortening of the tobacco rod length decreases $P_{\mathrm{t}}$ with time. The effect of rod length shortening is more significant than the other two factors. In fact, as the resistance to flow in the coal as a result of higher tempera- ture is increased, the flow is mainly redirected to enter from the circumference of the rod around the burn line where the resistance to flow is lower; thus, the changes in coal permeability have a slight effect on $P_{\mathrm{t}}$. On the other hand, the experimental results show a continuous increase of $P_{\mathrm{t}}$ with time. Unlike the coal, slight changes in permeability of the portion of the cigarette located downstream to coal change $P_{\mathrm{t}}$ considerably. In a continuous puffing situation, the generated smoke is continuously drawn and portions of it are deposited in tobacco rod and filter fibers. The filter pore size is much smaller than the tobacco rod pore size, and continuous deposition of smoke aerosols on the filter fibers would change its permeability. The change in permeability of the filter was verified experimentally. Samples of cigarette were smoked for four puffs and then the pressure drop (or resistance to draw, RTD) across the filters was measured and compared with the RTD of fresh filters. A slight increase in RTD, e.g., $5 \mathrm{~mm} \mathrm{H}_{2} \mathrm{O}$, for the smoked filters was observed. This simple test clearly shows that the filter permeability decreases with the length of burnt cigarette during puffing, which is proportional to the rate of movement of the burn line and duration time for a continuous smoking situation. Thus:

Change in filter permeability $=\alpha \times$ burn line speed $\times$ duration time $\times K_{\mathrm{ff}}$,

where $K_{\mathrm{ff}}$ is the permeability of fresh filter. For continuous puffing at $6.67 \mathrm{~cm}^{3} / \mathrm{s}$, burn line speed is $0.44 \mathrm{~mm} / \mathrm{s}$. A simple simulation along with a trial and error procedure yielded a value of 0.017 for $\alpha$ that produces a good agreement between the numerical and experimental results, as shown in Figure 10. It was further noticed that the calculation slightly underestimated $P_{\mathrm{t}}$ at the beginning of puffing. This is due to the fact that the effect of cigarette lighting is not simulated in this calculation.

\section{Puff-by-puff condition}

The changes in filter permeability need to be formulated first in a puff-by-puff situation. To do that, we assume the change in permeability is proportional to the total amount of smoke effluent, e.g., whole smoke, which in turn is proportional to the mass burn rate and puff duration. The mass burn rate is proportional to the rate (speed) at which the burn line is moving. Thus, for the puff-by-puff situation we have:

$$
\begin{aligned}
\alpha_{\text {puff -by-puff }} & =\alpha \frac{\text { burn rate of puff by puff condition }}{\text { burn rate of continuous puffing }} \\
& =\alpha \frac{0.52}{0.44}=0.02 \mathrm{~m}^{-1}
\end{aligned}
$$

For the puff-by-puff situation, a 2-second duration time was assumed for the puff. Then the puff-by-puff situation was simulated for a $17.5 \mathrm{cc} / \mathrm{s}$ flow volume/rate with a linear burn rate (LBR) of $0.52 \mathrm{~mm} / \mathrm{s}$, a coal length of $8.0 \mathrm{~mm}$ and a total of 9 puffs.

Figure 11 shows the velocity profile along the centerline of the cigarette for the fourth puff. The profile shows an intense peak for the velocity in the coal region. This is due to the high temperature in coal that causes air to expand and to increase the velocity, a behavior reported by BAKER (21). Figure $12 \mathrm{a}$ shows the velocity contours around the coal region. It is clear that there is a strong flow on the cigarette 


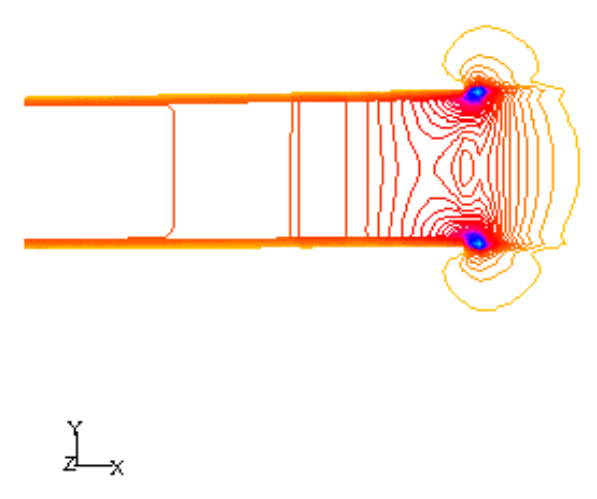

Figure 12a. Velocity $(\mathrm{m} / \mathrm{s})$ contours throughout the cigarette during puffing

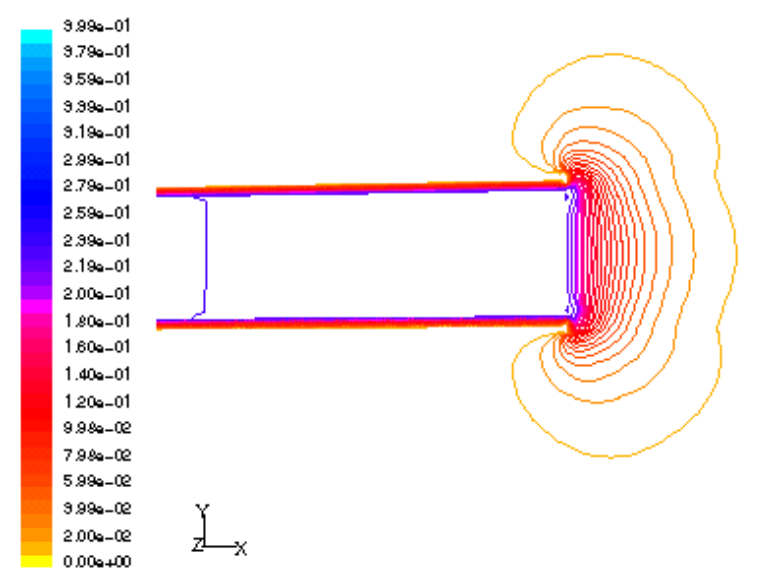

Figure 12b. Velocity $(\mathrm{m} / \mathrm{s})$ contours throughout the cigarette in dry puffing

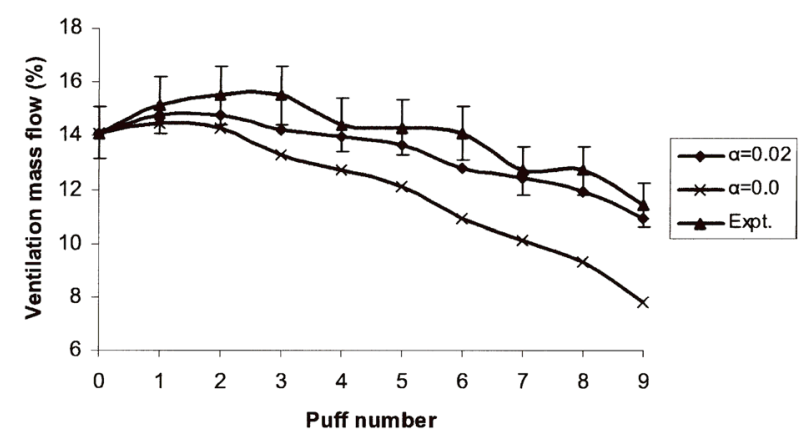

Figure 13. The variation of ventilation with puff number

circumference at the burn line with the air velocity reaching $1.65 \mathrm{~m} / \mathrm{s}$. The profile for air velocity is very different in an unlit cigarette (Figure 12b) where there is no coal and hot zone and air enters from all directions into the cigarette tip. Since in a burning cigarette the oxidation of tobacco is mainly controlled by the rate of oxygen transfer to the tobacco char (28-31), we expect to observe higher burn rates at locations where the air inflow is higher.

Figure 13 shows the numerical results for the variation of ventilation mass flow rate with puff number. The calculation was done for two cases: a case with constant filter

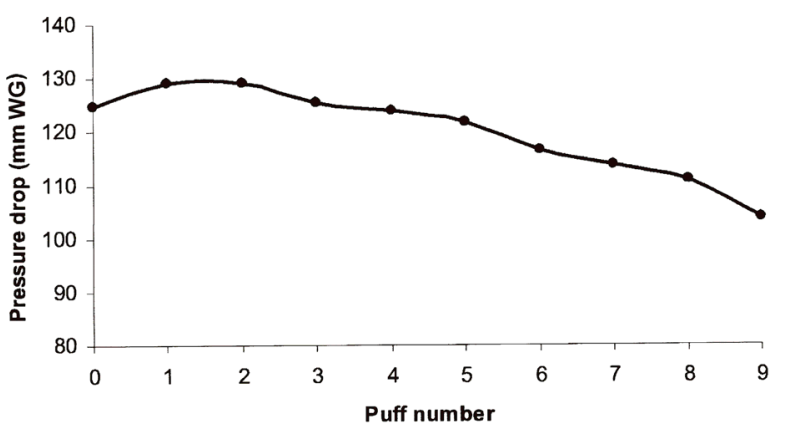

Figure 14. The variation of total pressure drop with puff number

permeability and another one where the filter permeability changes with the puff number. The mass flow rates are normalized to the cigarette total outlet mass flow rate. For comparison with experimental data, the values measured by PARRISH (32) are also depicted. It is clear that the calculated values with variable filter permeability are closer to the experimental values. The calculation with constant filter permeability predicts more reduction in ventilation per puff than expected.

The calculated results for the variation of the total pressure drop, RTD, as a function of puff number is shown in Figure 14. The RTD first tends to increase with the first two puffs and then begin to drop as the number of puffs increases. For the first two puffs, the increase in RTD due to effects of coal resistance at high temperature is stronger than the reduction in RTD due to the shortening of the cigarette rod. After the second puff, when RTD is mainly controlled by the cigarette rod, it monotonically decreases with puff number as the cigarette rod is shortened. The trend in variation of RTD with puff is very similar to that of ventilation. This is not surprising, since the mass flow rate for the ventilation is affected by the upstream pressure that is atmospheric pressure, and the pressure downstream to ventilation zone, which is very close to the pressure at the end of the filter. Thus, ventilation is mainly affected by RTD. For both RTD and ventilation mass flow rate, $20 \%$ of total reduction takes place for the last puff.

The centerline temperature of a burning cigarette, according to BAKER's temperature profile for puffs (33), drops to about $100{ }^{\circ} \mathrm{C}$ within $5 \mathrm{~mm}$ behind the cigarette burn line. Most of the smoke constituents that are formed by vaporization, distillation and pyrolysis are formed around the burn line, and smoke aerosols are formed and stabilized where the temperature has dropped to $100{ }^{\circ} \mathrm{C}$. Thus, the air mass flow rate between the char line and the location where the temperature has dropped to about $100{ }^{\circ} \mathrm{C}$ would have a strong effect both on the total delivery of smoke constituents and the size and distribution of smoke particles (20, 34-36). The result of Figure 15 indicates that the addition of ventilation and dilution would reduce the delivery of TPM and gaseous products in the same proportion for all the puffs. Also it is noticed that the mass flow through a section $5 \mathrm{~mm}$ behind the burn line is increasing with puff number. This trend indicates that in order to achieve a uniform delivery per puff, the mass flow rate behind the burn line should be kept the same for all puffs.

Figure 16 shows that the total air flow through the rod paper decreases with puff number, and this is consistent 


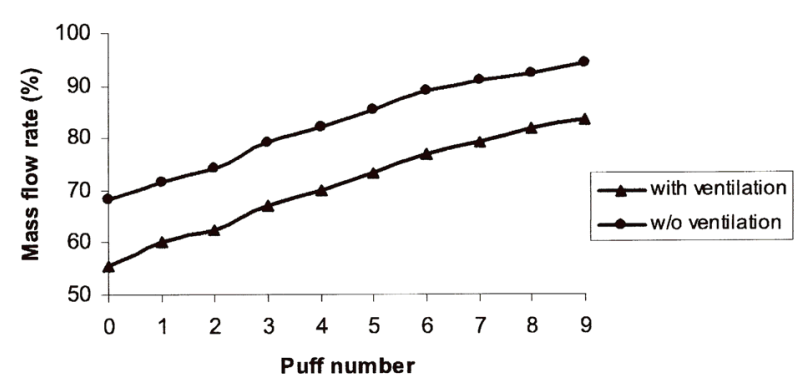

Figure 15. The variation of mass flow rate behind the burn line with puff number

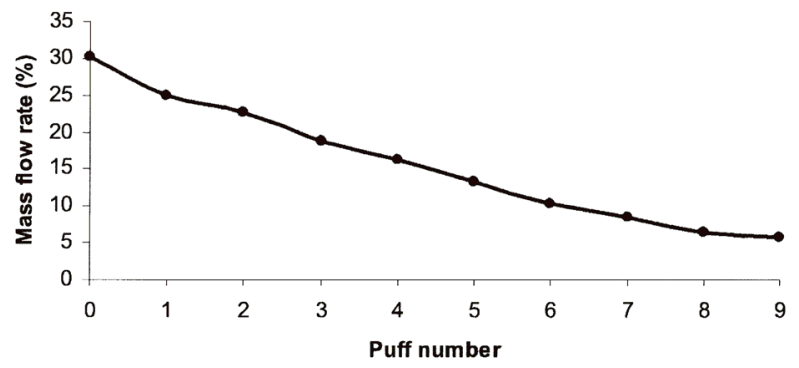

Figure 16. Variation of rod-paper mass flow rate with puff number

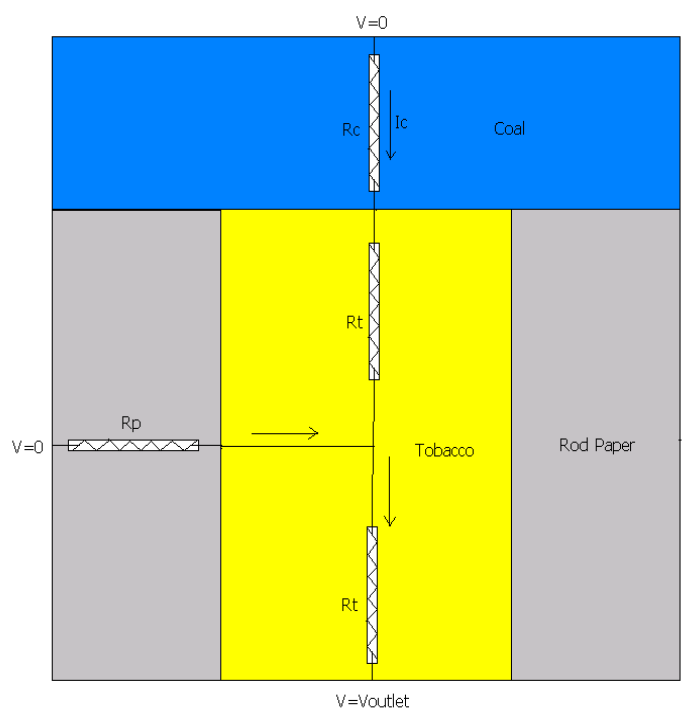

Figure 17. Equivalent electric circuit of a puffing cigarette

with the experimental results reported by MASUO (20) and BAKER (13). As a result, the total air flow through the coal and rod paper becomes almost constant. Given the fact that the total air flow is constant at the filter end for each puff, and air flow through the ventilation zone only slightly varies through the puffs, the constant total air flow through the coal and rod paper is considered to be rational. That is, as the air flow through the paper decreases with puff, the air flow through the coal must increase.

The trends given in Figures 14 and 15 can be predicted from the analogy between electric and potential flow fields.

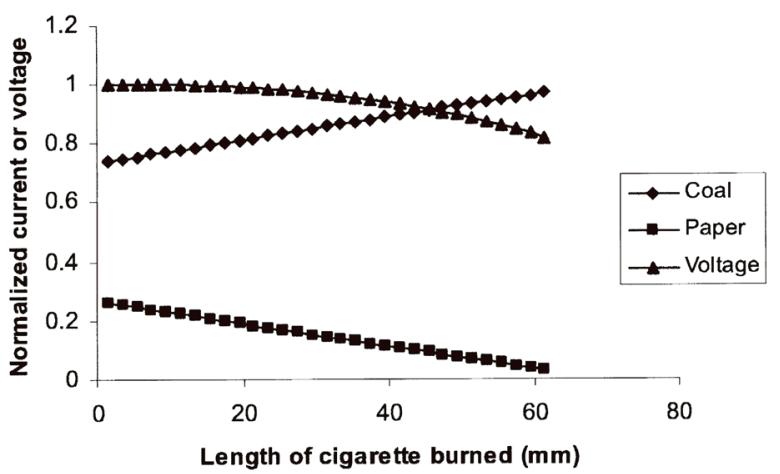

Figure 18. Variation of outlet voltage and coal current with length of cigarette burned

The pressure is considered as a voltage and the mass flow rate as an electric current. The flow resistance is derived from $V=R I$ correlation and Darcy's law.

$$
\begin{gathered}
\Delta P / L \approx \mu V / K=\mu \dot{m} / K \rho A \\
\Delta P=R \dot{m} \Rightarrow R=L \mu / K \rho A
\end{gathered}
$$

where $L, A$ and $K$ are the bed length, cross sectional area and permeability, respectively.

We represent the flow through the cigarette by a simple electric circuit depicted in Figure 17. $R_{\mathrm{c}}, R_{\mathrm{p}}$ and $R_{\mathrm{t}}$ represent the resistance to draw through the coal, wrapper paper and one half of the tobacco region, respectively. The currents and voltages may be calculated by applying Kirchoff's law to the above circuit. The current through the coal, $I_{c}$, and the outlet voltage (outlet pressure) may be calculated from Eqns. [7] and [8].

$$
\begin{gathered}
I_{\mathrm{c}}=\dot{m} \frac{R_{\mathrm{p}}}{R_{\mathrm{c}}+R_{\mathrm{p}}+R_{\mathrm{t}}} \\
V_{\text {outlet }}=\dot{m}\left(R_{\mathrm{t}}+\frac{R_{\mathrm{p}}\left(R_{\mathrm{c}}+R_{\mathrm{t}}\right)}{R_{\mathrm{c}}+R_{\mathrm{p}}+R_{\mathrm{t}}}\right)
\end{gathered}
$$

where $R_{\mathrm{c}}$ depends on the coal geometry, permeability and temperature which can be considered approximately the same for all puffs. Using Eqn. [6] we can derive equations for $R_{\mathrm{c}}$ and $R_{\mathrm{t}}$ as given below:

$$
\begin{aligned}
& R_{\mathrm{p}}=L_{\mathrm{p}} \mu /\left(2 \pi R L_{\mathrm{t}} \rho K_{\mathrm{p}}\right) \\
& R_{\mathrm{t}}=0.5 L_{\mathrm{t}} \mu /\left(\pi R^{2} \rho K_{\mathrm{t}}\right)
\end{aligned}
$$

Since we expect to see trends from the electric analogy rather than quantitative results, $I_{\mathrm{c}}$ was set equal to the $3-\mathrm{D}$ value corresponding to the first puff, and the $V_{\text {outlet }}$ was normalized to 1.0 at $L_{\mathrm{b}}=0.0$. The $I_{\mathrm{c}}$ and $V_{\text {outlet }}$ are calculated for different values of $L_{\mathrm{t}}$ and are presented vs. $L_{\mathrm{b}}$ in Figure 17. $L_{\mathrm{b}}$ is the length of tobacco burned which is proportional to the puff number. From Figure 18, one can see that the variation of $I_{\mathrm{c}}$ and $V_{\text {outlet }}$ with $L_{\mathrm{b}}$ shows a similar trend for RTD and mass flow rates as given in Figures 14 and 15. 


\section{CONCLUSIONS}

From a combination of the experimental results with the computational fluid dynamics simulation, a three-dimensional mathematical model was developed for the parametric study of puff hydrodynamics. The mathematical model was applied to predict the pressure and flow distributions inside and outside of a cigarette for the three cases, namely continuous puffing of an unlit cigarette, continuous puffing of a lit cigarette, and a normal puff-by-puff condition. The changes in coal and filter permeability during puffing were calculated by incorporating the experimental results of a continuous puffing condition into the mathematical model. For the puff-by-puff condition, the velocity and pressure distribution in the cigarette as well as the mass flow rates through the ventilation zone, wrapper paper and around the burn line were calculated for each puff. The air velocity profile shows a sharp peak in the coal region. The mass flow rate through the ventilation zone slightly decreases with puff number while the mass flow rate at and around the burn line has an increasing trend with the puff number.

\section{ACKNOWLEDGEMENT}

Authors wish to thank Isfahan University of Technology for granting sabbatical leave to Professor M.S. Saidi. The authors also thank Dr. P. Chen for his valuable comments. Many thanks to M.S. Rostami of Virginia Commonwealth University for performing the experimental work.

\section{REFERENCES}

1. Ohlemiller, T.J.: Modeling of smoldering combustion propagation; Prog. Energy Combustion Sci. 11 (1985) 277-310.

2. Summerfield, M, T.J. Ohlemiller, and H.W. Sandusky: A thermophysical mathematical model of steady-draw smoking and predictions of overall cigarette behavior; Combust. Flame 33 (1973) 263-279.

3. Norbury, J. and A.M. Stuart: A model for porousmedium combustion; Q. J. Mech. Appl. Math. 42 (1989) 159-178.

4. Kansa, E.J., H.E. Perlee, and R.F. Chaiken: Mathematical model of wood pyrolysis including internal forced convection; Combust. Flame 29 (1977) 311-324.

5. Leach, S.V., G. Rein, J.L. Ellzey, O.A. Ezekoye, and J.L. Torero: Kinetic and fuel property effects on forward smoldering; Combust. Flame 120 (2000) 346-358.

6. Muramatsu, M., S. Umemura, and T. Okada: A mathematical model of evaporation-pyrolysis processes inside a naturally smoldering cigarette; Combust. Flame 36 (1979) 245-262.

7. Sandusky, H.W.: A computer-simulated cigarette model for use in the development of less hazardous cigarette; Ph.D. Thesis, Princeton University, Princeton, NJ, 1976.

8. Di Blasi, C.: Modeling and simulation of combustion processes of charring and non- charring solid fuels; Prog. Energy Combust. Sci. 19 (1993) 71-104
9. Yi, S., E. Song, and M.R. Hajaligol: Mathematical model of smoldering combustion in a carbonaceous porous medium, Part 1-development of pyrolysis and combustion models for a cylindrical geometry; Fire Sci. 19 (2001) 429-448.

10. Rostami, A., J. Murthy and M.R. Hajaligol: Modeling of a smoldering cigarette; J. Anal. Appl. Pyrolysis 66 (2003) 281-301.

11. Rostami, A., J. Murthy, and M.R. Hajaligol: Modeling of the smoldering process in a porous biomass fuel rod; Fuel 83 (2004) 1527-1536.

12. Rostami, A., J. Murthy, and M.R. Hajaligol: Modeling of a smoldering carbonaceous rod; Am. Chem. Soc. meeting; Fuel Division, Orlando, FL, April 2002.

13. Baker, R.R.: The effect of ventilation on cigarette combustion mechanisms; Rec. Adv. Tob. Res. 10 (1984) 88-150.

14. Baker, R.R. and R.A. Crellin: Diffusion of carbon monoxide out of cigarettes; Beitr. Tabakforsch. Int. 9 (1977) 131-140.

15. DeLucia, M.L., C.F. Mattina, and W.A. Selke: Physical parameters that affect composition of smoke; Rec. Adv. Tob. Sci. 6 (1980) 225-238.

16. Masuo, Y., Y. Suga, M. Shibata, A. Terahara, M. Hatakeyama, K. Takeda, N. Yasumatsu, M. Yamazaki, T. Akaki, R. Watanabe, and H. Tanaka: Effect of the degree of perforation of cigarette paper and tipping paper on the performance of filter cigarettes; Part 10, Effect of the components and vented cigarettes on the delivery of smoke constituents and smoking quality; Sci. Papers Cent. Res. Inst. Japan Tobacco \& Salt Monop. Corp. 123 (1981) 79-89.

17. Owen, W.F. Jr.: Effect of cigarette paper on smoke yield and composition; Rec. Adv. Tob. Sci. 4 (1978) 3-24.

18. Terahara, A., M. Hatakeyama, K. Maeda, K. Takeda, T. Sawaguri, F. Kondo, Y. Ikuta, and K. Noguchi.: Effect of the degree of perforation of cigarette paper and tipping paper on the performance of filter cigarettes, Part 7, On the pressure drop, ventilation rate, delivery of smoke constituents and the reduction of vapor phase components; Sci. Papers Cent. Res. Inst. Japan Tobacco \& Salt Monop. Corp. 122 (1980) 103-113.

19. Norman, V.: The effect of perforated tipping paper on the yield of various smoke components; Beitr. Tabakforsch 7 (1974) 282-287.

20. Masuo, Y., N. Yasumatsu, M. Shibata, and H. Tomita: Effect of the degree of perforation of cigarette paper and tipping paper on the performance of filter cigarettes, Part 11. On the relationship between burning characteristics and delivery of smoke constituents; Sci. Papers Cent. Res. Inst. Japan Tobacco \& Salt Monop. Corp. 123 (1981) 91-100.

21. Baker, R.R.: Gas velocities inside a burning cigarette; Nature 264 (1976) 167-169.

22. Schneider, W., A. Wenger, D. Hoffmann, and T.C. Tso; The effects of the properties of materials in a cigarette on filter ventilation; Beitr. Tabakfosch. Int. 12 (1984) 123-136.

23. Dullien, F.A.L.: Porous media fluid transport and pore 
structure; Elsevier Science (USA), $2^{\text {nd }}$ Ed., 1992, pp. 237-240.

24. Warsi, Z.U.A.: Fluid dynamics, theoretical and computational approaches; CRC press, USA, $2^{\text {nd }}$ Ed., 1999, $58-59$.

25. Doormal, V. and G.D. Raithby: Enhancements of the SIMPLEC method for predicting incompressible fluid flow; Numer. Heat Transfer 7 (1984) 147-163.

26. Ferziger, J.H. and M. Peric; Computational methods for fluid dynamics, $2^{\text {nd }}$ Ed., Springer-Verlag, Berlin, 1999, pp. 74-75.

27. FLUENT 6.0 UDF Manual, Fluent Inc., Lebanon, NH, Nov. 29, 2001.

28. Baker, R.R.: The kinetics of tobacco pyrolysis; Thermochim. Acta 17 (1976) 29-63.

29. Guan, K.: Natural smoldering in cigarettes; Combust. Flame 10 (1966) 161-164.

30. Muramatsu, M., S. Umemura, and Okada, T.: Consumption of oxygen and heat evolved during natural smolder of a cigarette; J. Chem. Soc. Japan, Chem. Ind. Chem. 10 (1978) 1441-1448.

31. Muramatsu, M.: Studies on the transport phenomena in naturally smoldering cigarettes; Sci. Papers Cent. Res. Inst. Japan Tobacco \& Salt Monop. Corp. 123 (1981) 9-77.

32. Parrish, M.E., C.N. Harward, and G. Vilcins: Simultaneous monitoring of filter ventilation and a gaseous component in whole cigarette smoke using tunable diode laser infrared spectroscopy; Beitr. Tabakforsch. Int. 13 (1986) 169-181.
33. Baker, R.R.: Temperature variation within a cigarette combustion coal during the smoking cycle; High Temp. Sci. 7 (1975) 236-247.

34. Ishizu, Y., K. Ohta, and T. Okada: Changes in the particle size and concentration of cigarette smoke through the column of a cigarette; J. Aerosol Sci. 9 (1978) 25-29.

35. Keith, C.H.: Physical mechanisms of smoke filtration; Rec. Adv. Tob. Sci. 4 (1978) 25-45.

36. Morrie, G.P. Selective filtration of tobacco smoke components: Proceedings 173rd Am. Chem. Soc. Symp., Recent advances in the chemical composition of tobacco and tobacco smoke, 1977, pp. 553-583.

Address for correspondence

Mohammad R. Hajaligol

Research Center

Philip Morris USA

Richmond, Virginia 23234

USA 